\title{
Determinants of International Beer Export
}

\author{
Eva Bieleková, Ján Pokrivčák
}

Department of Economic Policy, Faculty of Economics and Management, Slovak University of Agriculture in Nitra, Slovakia

\begin{abstract}
The aim of this paper was to identify factors influencing dynamics of international beer export. The Poisson pseudo maximum likelihood estimator was employed to estimate the export determinants of the biggest global beer exporters to 199 destinations between 2000 and 2017. We estimated that international beer export is positively influenced by gross domestic product of importing countries and cultural similarities. Trade between countries that share common borders, same language or colonial links has shown to be a very strong and positive determinant. We found a significant role of customs unions and signed free trade agreements; however, this result was not robust across all estimated models. Beer export is negatively affected by the distance between trading countries and their landlockedness, which confirms the relevance of transport cost in beer trade. Beer exports are declining with rise in population of importing countries, which signals an advantage in targeting countries with less differentiated beer supply.
\end{abstract}

\section{Keywords}

International trade, export analysis, gravity model, PPML, beer

Bieleková, E. and Pokrivčák, J. (2020) "Determinants of International Beer Export", AGRIS on-line Papers in Economics and Informatics, Vol. 12, No. 2, pp. 17-27. ISSN 1804-1930. DOI 10.7160/aol.2020.120202.

\section{Introduction}

The last few decades have been characterised by significant changes in the global beer markets. Historically highly fragmented global beer industry has gone through a process of consolidation via mergers and acquisitions (M\&As). Increasing concentration lead primarily by utilization of the economy of scale reduced the number of competitors on the market and resulted in less variety and unification of beer products (Tremblay and Tremblay, 2004; Madsen and $\mathrm{Wu}, 2016$ ). At the same time, a trend of premiumisation of the production motivated by consumers' interest in new, exclusive and origin-specific products has taken off (Goméz-Corona et al., 2016). In the US and Western Europe, the craft beer segment expanded substantially, bringing back high product diversity to consumers who nowadays drink less but they search for higher quality products. Formation and expansion of craft breweries started in the 1970s in the USA. Western Europe joined the trend in 1980s, while in Eastern Europe, Slovakia including, the craft beer revolution started after year 2000 (Pokrivčák et al., 2019 and 2017).

Changes in the structure of beer markets have significant influence on international trade.
From the early decades of the $20^{\text {th }}$ century, the beer production has been growing globally. Initially, Europe was the biggest producer of beer. After the 1950s, however, American and Asian countries gradually begun to catch up with the European levels of production, what together with other factors contributed to the rise of world beer trade. Despite growing international beer trade, only around $15 \%$ (in 2017) of the global beer production is traded (Figure 1).

Global beer export more than doubled since the year 2000, and currently it amounts to 15.1 billion litters a year (value of 14.3 billion dollars). The top world beer exporter Mexico is followed by the Netherlands, Belgium and Germany, while the largest amount of beer is produced in China, the United States, Brazil, Mexico, and Germany. In 2017, the European countries contributed to the global beer export with $57.1 \%$ and North American share reached $32 \%$. On the other hand, the leading beer importing area is North America (42\% of the world beer imports) followed by Europe with the share of $35 \%$.

Beer trade is also driven by changes in beer consumption. Consumption in typical beer countries such as United Kingdom, Germany, Denmark 


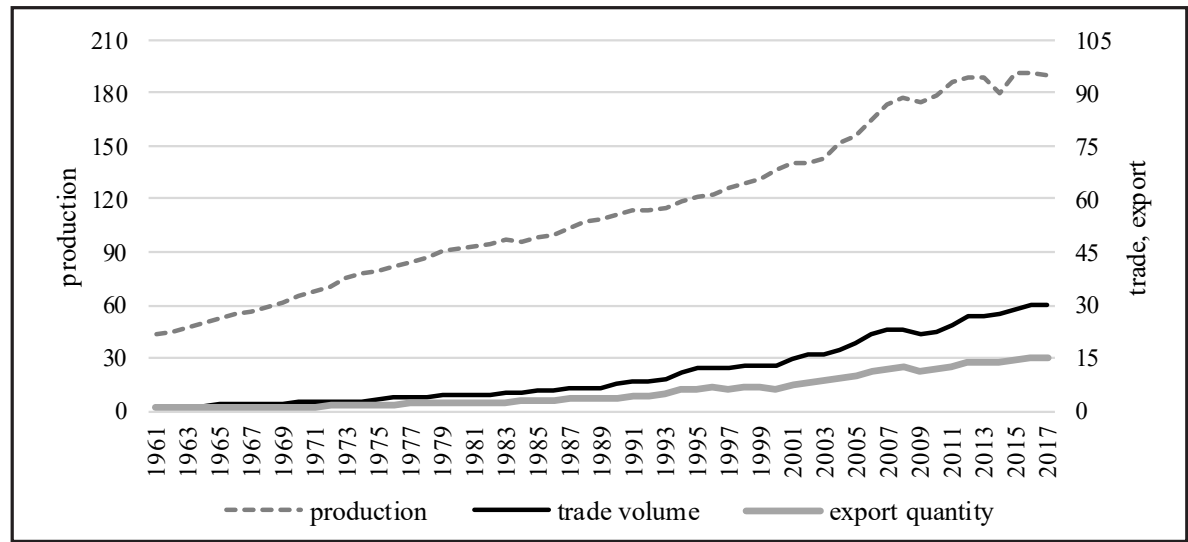

Source: FAO and Kirin Beer University database, UN Comtrade

Figure 1: Development of world beer production, trade volume and export in billion litters.

or Belgium shows a downward trend; in case of the world's leading per capita beer consumer, Czechia, the consumption does not rise in the long run (see Figure 2). On the other hand, a significant increase in beer consumption has occurred in emerging economies and in Asian and African countries. According to Swinnen (2017), globalization and income are the main factors responsible for changing beer drinking patterns. As income rises, poorer people spend more on beer but at some point, the positive effect of income growth on beer consumption reverses. One possible explanation is that people become more aware of health risks of alcohol consumption, another that with higher income, they can buy also more expensive alcoholic drinks such as wine or spirits. Other important factor influencing global beer consumption and trade is religion. Some religions, e.g. Islam, Buddhist or Mormon, do not allow the consummation of alcohol (Ashley and Rankin, 1988). That accordingly limits trade with countries where the share of non-drinkers is substantial.

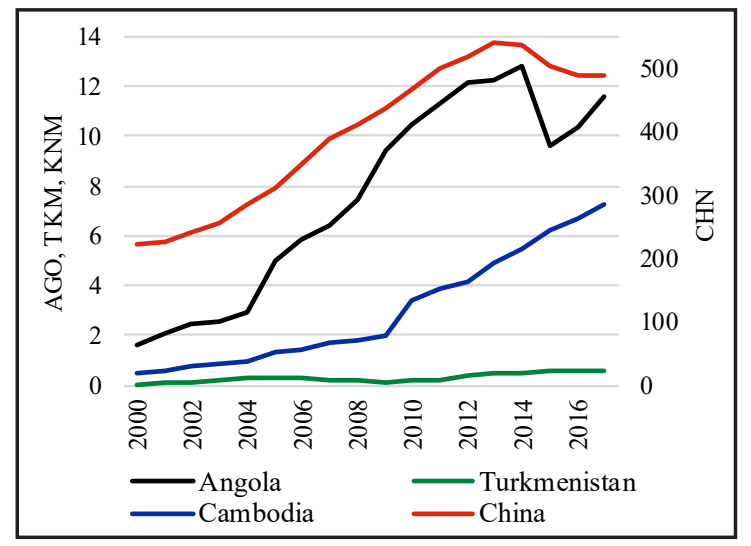

Source: GlobalData database

Figure 2: Development of beer consumption of selected countries in $2000-2007$ in million hl. ( $1^{\text {st }}$ part $)$.

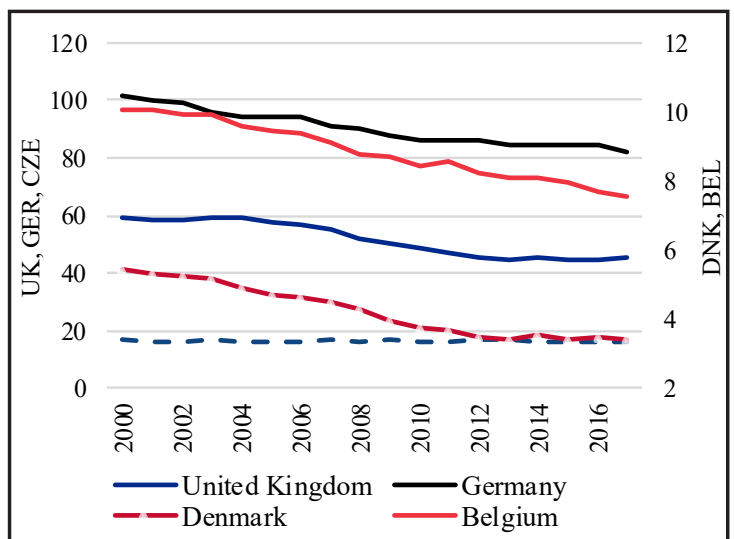

Source: GlobalData database

Figure 2: Development of beer consumption of selected countries in $2000-2007$ in million hl. ( $2^{\text {nd }}$ part $)$.

Beer comprises mostly water, thus, its trade costs are high. Because of high trade costs, firms in the beer industry tend to localize their production near consumers (Olper et al., 2012). As an answer to the decline of beer consumption, brewing companies were forced to consolidate and to use in-country production licences (McGowan and Mahon, 2007). Furthermore, many countries use protectionist policies (e.g. tariffs, government standards and laws, certifications, testing of consignments, excise duties), which create additional restrictions to trade with alcoholic beverages (Bjelić, 2016). The effect of tariff barriers can be lowered when regional and preferential trade agreements (RTA and PTA) exist between the trading partners. Zeigler (2008) finds that free trade agreements (FTA) lead to reduction of trade barriers, they increase competition in the alcohol industry and by that contribute to the decline of alcohol prices. FTAs affect both tariff and non-tariff barriers; they contain services, investment or intellectual property rights (Wine institute, 2019). 


\section{Gravity and trade}

Quantity and value of beer exports to foreign markets depend heavily on characteristics of domestic and world markets. Gravity model of trade is often used to study the effects of characteristics of domestic and international markets on trade. Most studies using gravity model analyse total foreign trade. A smaller number of studies focuses on analysing foreign trade changes of specific commodities such as alcoholic beverages in general or beer in particular. For example, Pinilla and Serrano (2008) evaluated the role of trade policies in Spanish table wine export. Balogh (2015) examined global wine trade flows with the conclusion that cultural similarities and trade agreements between trading partners lower the cost of wine export. Bouët et al. (2017) found that as it is in case of other luxury products, the distance elasticity of cognac exports is negative but relatively small, while the elasticity to GDP is positive and relatively large. According to Dal Bianco et al. (2015), trade costs do matter considerably in case of wine trade: tariffs have the largest impact followed by geographical distance. The findings of De Matteis et al. (2018) suggest that technical barriers to trade adversely impacted the exports of distillers dried grains with solubles to an extent larger than the influence of tariff. In case of beer, gravity with combination of pricing to market model was used by Dreyer et al. (2017) to identify factors enhancing German beer export. The authors found that German beer export is strongly affected by the membership of trading partners in the EU and introduction of the Euro.

To our knowledge, there are only few studies investigating factors influencing beer exports, i.e. why beer is traded to particular countries and which factors stimulate the beer trade positively and otherwise: Dreyer et al. (2017) examined German beer exports during 1991 - 2010; Olper et al. (2012) analysed EU bilateral beer and wine exports during 2000 - 2009; McGowan and Mahon (2007) analysed the impact of NAFTA on US beer trade flows during $1992-2001$. In this paper using gravity modelling, we aim to identify the factors stimulating current international beer export dynamics. It is important to know how structural changes in global beer market affected trade with beer. Based on empirical studies presented in the introduction of the paper, we expect some of the selected variables to act as trade attractors and other as trade frictions. Regarding that, we test the following hypotheses:

H1: GDP of importing countries and beer exports to these countries have a directly proportional relationship.

$\mathrm{H} 2$ : Exporting beer to countries sharing a common language lowers trade cost and increases beer export.

H3: Beer export rises with a decrease in geographical distance between trading countries.

H4: Trade liberalisation (FTAs, customs unions) positively affects beer export.

\section{Materials and methods}

Gravity model is used for modelling the allocation of traded goods transmitted from the export country (i) to the destination (importing) country $(j)$. In terms of international trade assessment, the model origins with Tinbergen (1962), who proposed that bilateral trade flows between countries can be approximated by employing the Newton's gravity equation. In its basic form, the gravity equation for trade can be written as

$T_{i j}=a_{0} Y_{i}^{a_{1}} Y_{j}^{a_{2}} D_{i j}^{a_{3}} \varepsilon_{i j}$,

where $T_{i j}$ is trade flow from country $i$ to country $j$, which is directly proportional to the gross domestic product (GDP) of $i$ and $j$ and inversely proportional to the distance between $i$ and $j . a_{0}, a_{l}$, $a_{2}$ and $a_{3}$ represent unknown (estimated) parameters and $\varepsilon_{i j}$ is the error term. In empirical studies the basic model is extended by variables, which according to the trade theory can influence the trade flows between countries: economic attractors of export, semi-economic or political factors, trade frictions and factors representing trade costs.

The estimation of the gravity equation can be done by different methods. First, the natural logarithms of all variables can be taken to create a log-linear gravity equation standardly estimated by Ordinary least squares (OLS):

$\ln T_{i j}=\ln a_{0}+a_{1} \ln Y_{i}+a_{2} \ln Y_{j}+a_{3} \ln D_{i j}+\ln \varepsilon_{i j}$.

The data, however, includes zero trade observation, i.e. situation when in a particular time period some pairs of countries did not trade or when there are missing values. As the logarithm of zero is not defined, it creates a problem for the use of the loglinear gravity equation. The zero trade flows could be omitted in the sample, but we would lose a part of trade information, or/and it could lead to biased results (Burger et al., 2009). One of the techniques used for treating zero values is employing the Poisson pseudo maximum likelihood (PPML) 
estimator as proposed by Silva and Tenreyro (2006), which can be applied to the original nonlinear form of gravity model. Another benefit of PPML is that it accounts for heteroscedasticity, which is an often characteristics of trade data. Pokrivčák et al. (2013) used PPML to model global dairy trade and estimate the impact of Russian NTMs on dairy imports.

We extend the equation (1) by including all the relevant variables affecting beer exports. As our dataset includes zero export flows, we will estimate the multiplicative gravity function with PPML estimator. The estimated model takes the following general form

$$
\begin{aligned}
& E X_{i j t}=\exp \left(\ln a_{0}+a_{1} \ln g d p_{i t}+a_{2} \ln g d p_{j t}\right. \\
& +a_{3} \ln \text { pop }_{j t}+a_{4} \ln \operatorname{prod}_{i t}+a_{5} \text { contig }_{i j} \\
& +a_{6} \text { comlang }_{i j}+a_{7} \text { curcol }_{i j}+a_{8} \text { smctry }_{i j}+a_{9} \text { curr }_{i j t} \\
& +a_{10} \text { FTA }_{i j t}+a_{11} C_{i j t}+a_{12} \ln \text { dist }_{i j}+a_{13} \text { land }_{i j} \\
& \left.+a_{14} \text { island }_{j}+a_{15} \text { Eur }_{j}+a_{16} \ln \text { ndrel }_{j}+\mu_{i j t}\right)
\end{aligned}
$$

where:

$E X_{i j t}$ - volume of beer export from export country $i$ to import country $j$ in year $t$ in millions of litters and billions of US dollars

$a_{1}-a_{16}-$ estimated elasticities of variables

$a_{0}-$ constant

$\mu_{i j t}-$ country-specific and time-specific factors estimated as fixed effects capturing unobserved variability

$\varepsilon_{i j t}$ - error term

$g d p_{i t}$ and $g d p_{j t}-$ gross domestic product of $i$ and $j$ in billion USD

pop $_{j t}$ - population of $j$ in millions of people $\operatorname{prod}_{i t}$ - beer production of $i$ in millions of litters contig $_{i j}$ - dummy variable (dummy) equal unity when $i$ and $j$ have common borders

comlang $_{i j}$ - dummy equal unity when $i$ and $j$ share the same official language

curcol $_{i j}$ - dummy equal unity when currently $i$ and $j$ have a colonial link

smctry $_{\mathrm{ij}}$ - dummy equal unity when $i$ and $j$ are/were part of the same country

curr $_{i j t}$ - dummy equal unity when $i$ and $j$ use common official currency

$F T A_{i j t}$ - dummy equal unity when $i$ and $j$ have a signed free trade agreement

$C U_{i j t}$ - dummy equal unity when $i$ and $j$ are members of a customs union

dist $_{i j}$ - average distance of $i$ and $j$ in $\mathrm{km}$

land $_{i j}$ - dummy equal unity when $i$ or $j$ are landlocked countries

island $_{j}$ - dummy equal unity when $j$ is an island
$E u r_{j}$ - dummy equal unity when $j$ is a European country

$n d r e l_{j}$ - share of adherence of religions that do not allow alcohol consumption

\section{Description of variables and data sources}

To estimate effects of factors influencing the international beer export, a balanced panel dataset is created, i.e. the zero observation of the dependent variable are included. International beer export is represented by export volumes of the biggest global beer exporting countries (Belgium, China, Czech Republic, Denmark, France, Germany, Ireland, Italy, Mexico, Netherlands, Poland, Spain, Portugal, United Kingdom and USA); their exports account for more than $87 \%$ of global beer export (Table 1). The dependent variable is the annual volume of export in mil. litters and in billion US dollars from 15 selected reporters to 199 importing countries in the period of 2000 - 2017. Export data was extracted from UN Comtrade Database (corresponding to the harmonised system code HS4 2203).

\begin{tabular}{|l|c|c|}
\hline Reporter & $\mathbf{2 0 0 0 - \mathbf { 2 0 1 7 }}$ & Share, $\%$ \\
\hline Mexico & 34.0 & 19.5 \\
\hline Netherlands & 31.4 & 18.0 \\
\hline Germany & 20.4 & 11.7 \\
\hline Belgium & 17.1 & 9.8 \\
\hline United Kingdom & 12.5 & 7.2 \\
\hline USA & 6.4 & 3.7 \\
\hline Ireland & 5.5 & 3.2 \\
\hline Denmark & 5.5 & 3.1 \\
\hline France & 5.2 & 3.0 \\
\hline Czechia & 3.5 & 2.0 \\
\hline Portugal & 2.9 & 1.6 \\
\hline Italy & 2.2 & 1.3 \\
\hline China & 2.1 & 1.2 \\
\hline Spain & 2.0 & 1.1 \\
\hline Poland & 1.6 & 0.9 \\
\hline Total world export & 174.1 & \\
\hline Share on global export & & 87.4 \\
\hline
\end{tabular}

Source: UN Comtrade, 2019

Table 1: World beer export in $2000-2017$ in billion US dollars.

First explanatory variables are conventional gravity model variables gross domestic product (GDP) of exporting countries $i$ and GDP of importing countries $j$. Data on GDP is expressed in million USD (current prices) and retrieved from the World Bank database. In case of exporter, GDP represents its productive capacity. We expect that increase 
in GDP will increase the exporters' production possibilities and by that the availability of goods for export. GDP of importers represents a proxy for purchasing power of consumers. As beer is considered a normal good, we expect an income growth to cause a rise of beer demand.

The population of importing country represents potential consumers of beer. However, no a priori relationship between population and trade has been identified in other studies. A positive sign would mean that bigger countries (in terms of population) can absorb more of goods traded; a negative sign according to Giorgio (2004) means that growing population has a need for more differentiated supply of goods or that the more populated the countries are, the larger is their own production of goods. Data on population size of the 199 importing countries is taken from the World Bank database.

The production variable is used as a proxy for output capacity (supply) of exporters. We expect the coefficient of the variable be positive. Production data are drawn from Food and Agriculture Organization Corporate Statistical database (FAOSTAT) and Kirin Beer University database.

Data on average distance between the trading countries comes from CEPII database, which calculates distance between countries considering the 25 most populated cities of each country weighted by the share of the cities in country's total population. Distance variable is used as a proxy for transport costs of trade. According to Buch et al. (2004) and Márquez-Ramos et al. (2007), the magnitude and sign of the distance coefficient are related to the importance of bilateral activities with partners that are far away relative to those that are located nearby. We expect that beer export will be negatively influenced by the geographical distance of trading partners.

CEPII database was also used to acquire data on common official language, common borders, colonial history of trading countries and data on countries that once were or currently are a part of the same state. Trade with neighbouring countries can be beneficial, as it reduces transport costs. We included a dummy variable to control for this effect and expecting its coefficient to be positive. Other variables related to transport costs are dummy variables: land ${ }_{i j}$, which takes the value of 1 when $i$ or $j$ from a trading country-pair is landlocked, and island, equal unity when $j$ is an island. In both cases, a country being isolated by water or by other countries hindering the water access creates additional transport costs of trade. We do not use an island dummy for the exporters; even if United Kingdom and Singapore are island countries, they are using man-made causeways for ground transportation.

Trade costs not only include costs of transportation, they also can be related to exchange rates. The logic behind that is that common currency of a trading country-pair reduces the exchange rate volatility (Costa-i-Font, 2010) and eliminates transaction costs due to use of different currencies (Albertin, 2008), i.e. it decreases the cost of trade. To capture this effect, we include the variable common currency (data taken from World atlas.com). Many studies were done on this topic, however, there is no consensus on significance of the effect of common currency on trade. Some studies found a positive influence of common currencies and monetary unions on trade volumes, e.g. Rose and Stanley (2005) or Baldwin et al. (2005), who analysed the effect of euro, but no significant effect was determined by Thom and Walsh (2002) in case of Anglo-Irish trade and sterling currency union or Berger and Nitsch (2008) in case of European economic and monetary union. We expect a common currency used by trading countries to lower the trade costs and enhance beer trade.

The language variable is added to capture possible effect of common official language of trade partners on export. Speaking the language of the trading partner is essential in terms of negotiating contracts, handling legislative formalities but also for consumers who need to have sufficient information about the product on the label. We expect the language factor to have a positive effect on beer trade. A positive coefficient sign is expected in case of variables common colonial link of trading countries and the fact that they are/were a common country as well.

Data on adherence fractions of population of different religion groups and atheists in 2000 was retrieved from the World Christian Database. We estimated the share of people belonging to religions not allowing alcohol consumption (Muslims and Buddhists) on countries' total population number. The expectation is that the higher the share of non-drinkers in importing country, the lower the beer export.

Beer consumption in typical European beerdrinking countries is currently falling, which can influence beer exports to Europe. The variable Eur ${ }_{j}$ is included to capture these changes on the international beer market. 
As mentioned in the literature review, the relatively high trade cost of beer can be lowered when creating political and semipolitical relations to other countries, e.g. customs union, trade agreements. Customs unions (CU) allow free movement of goods and services, free trade agreements (FTA) decrease or eliminate tariffs and trade barriers. We expect, therefore, a positive coefficient of customs union and FTA variables. Data on CU and FTA comes from the Regional trade agreements information system (RTA-IS) of WTO.

We include fixed effects represented by a different set of dummy variables to control for other unobserved and omitted variables: time fixed effects capture the export variation over time and shocks affecting export flows; bilateral country pair fixed effects capture any unobserved relations and effects between country pairs constant over time; and exporter and importer fixed effects are used to control for variables specific to exporter or importer country, e.g. factor endowments, geographic terms, other factors specific to an exporter or importer of beer.

\section{Statistical analysis}

For econometric estimation, we use the STATA 13.1 software. As dataset includes zero observation of the dependent variable (i.e. when no trade between $i$ and $j$ occurs), we applied the PPML estimation method suggested by Silva and Tenreyro (2006).

We estimate several models with dependent variable expressed in value and in quantity terms differing in fixed effects included to account for different kinds of unobserved variability. For models A and $\mathrm{D}$, we introduce exporters and time fixed effects; for models B and E, we additionally include importer fixed effects; and for models $\mathrm{C}$ and $\mathrm{F}$, we introduce bilateral country pair and time fixed effects.

To test the adequacy of the estimated models, we perform the Ramsey regression equation specification error test (RESET) (Ramsey, 1969). The null-hypothesis states that all coefficients are zero. When the corresponding p-value is lesser than 0.05 , the null-hypothesis is rejected, and the model suffers from misspecification (i.e. another functional form is more fitted).

As suggested in Shepherd (2013), the robust option in STATA is employed to estimate standard errors robust to arbitrary patterns of heteroscedasticity. We assume that the error term is uncorrelated across clusters (i.e. across pair of trading countries) but correlated within a cluster. Thus, the distance variable $\left(\right.$ dist $\left._{i j}\right)$ specific to each country pair is used for clustering in data to avoid understated standard errors (Moulton, 1990).

\section{Results and discussion}

The estimation results for all estimated models are reported in Table 2. To test models' adequacy, the RESET test was performed, and its p-values are displayed at the bottom of table 2 . In case of model $\mathrm{A}$ and $\mathrm{D}$, we reject the null hypothesis, which indicates that these models are inappropriately specified. Other models pass the RESET test, and we will use them for interpretation. Together with explanatory variables these models explain $87-95 \%$ of the variability in international beer export. Most of the explanatory variables are statistically significant, and coefficients have the expected signs.

GDP of importing countries is according the estimated p-value statistically significant at the $1 \%$ level, and its coefficient has a positive sign for both models in terms of quantity and in terms of value. This confirms the hypothesis $\mathrm{H} 1$ and suggests that an increase in the importing country's GDP would be followed by an increase in exports to the country. Specifically, the estimated coefficients have the value of $0.66-0.89$ for value of export and $1.06-1.27$ for quantity of export. We can conclude that by its consumers, beer is considered a superior good. Our results are consistent with other studies, which report the income elasticity of beer be positive; for most countries and products, the coefficient ranges from 0.35 to 0.9 (Fogarty, 2010), in case of German beer export from 0.60 to 0.96 (Dreyer et al., 2017). The income growth in exporter country proved to have no significant influence on international beer export.

Exporter's supply capacity was proxied by the production variable. The authors of the study by Olper et al. (2012) dealing with European wine and beer export state that the standard level on the product level is frequently less than 1.0. However, we could not confirm a statistically significant influence of the production variable. Results reveal that change in beer exports is not significantly linked to a change in production of the exporters. It could mean that exporter countries produce enough beer to allocate it abroad, and there are other factors determining the changes of export activity (e.g. consumption changes in export countries, economies of scale). 


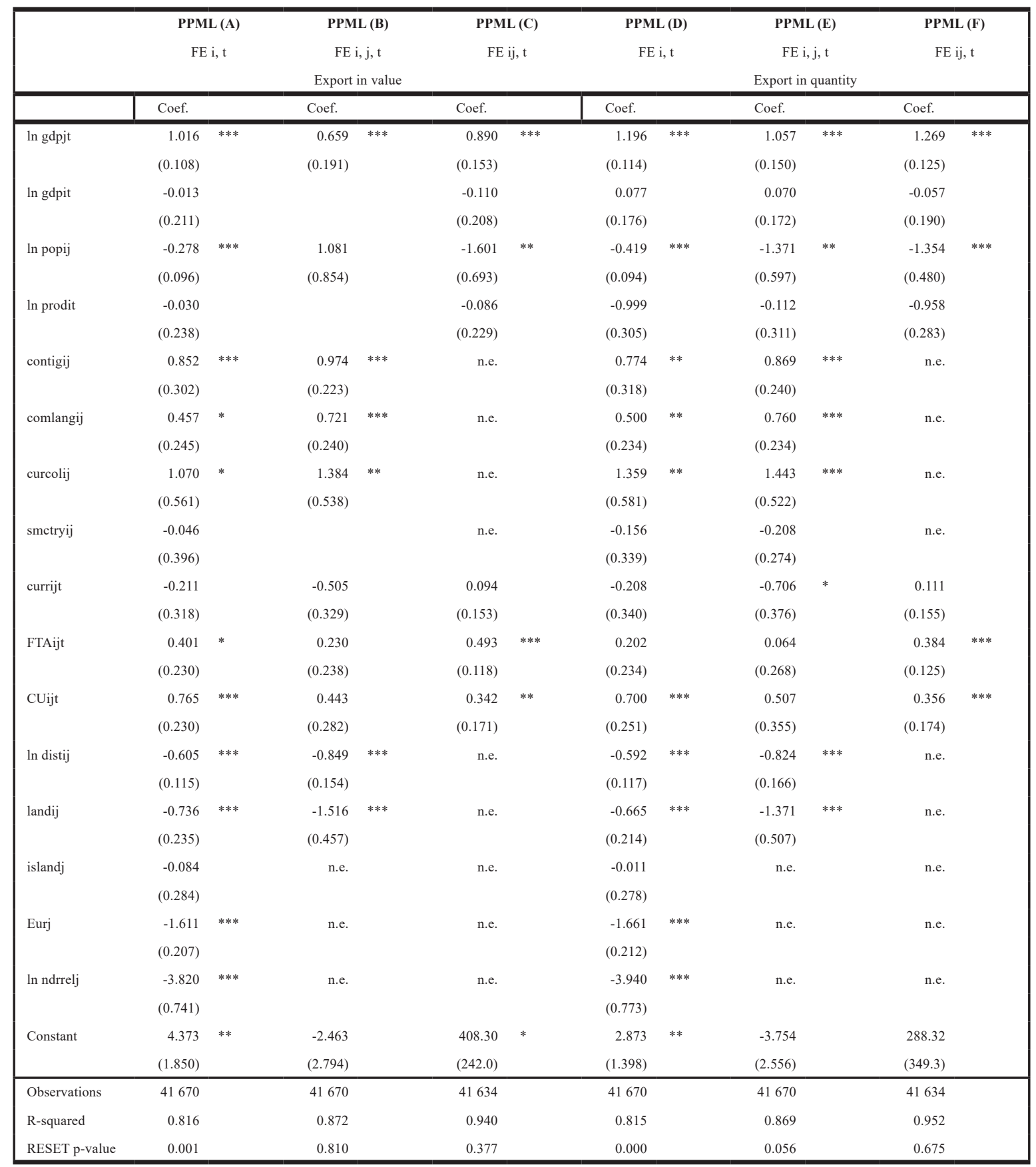

Note: Significant at: $* * * \mathrm{p}<0.01, * * \mathrm{p}<0.05, * \mathrm{p}<0.1$. Robust standard errors are displayed in parentheses; the fixed effects are omitted for brevity; n.e. denotes variables, which were dropped to avoid perfect collinearity with fixed effects Source: own estimations

Table 2: Estimation results.

The population variable is significant and has a negative sign. We can interpret this results in accordance with Giorgio (2004), thus, for the beer exporters, it has a greater advantage to export to less populated countries with smaller self-production or less differentiated supply of beer. Similar result is obtained also in Ekanayake et al. (2010) or by Anderson (1979).
Some trading countries in our sample use the same official language. This variable is especially important in the case of bottled or canned beer, which has to contain detailed product information (on the label) in the language of the importing country. This variable is strongly statistically significant (i.e. hypothesis $\mathrm{H} 2$ is confirmed at the $5 \%$ 
level) and ranges between $0.72-0.76$. It shows that trading countries sharing common language tend to trade $105-114 \%(\exp (0.72)-1=1.05)$ more than otherwise. In contrast, the language variable was not significant in case of European (Olper et al., 2012) and German (Dreyer et al., 2017) beer export. According to Olper, the insignificance can be due to multicollinearity between contiguity and language, as EU countries sharing common border shared also a common language.

Another factor, which was expected to have a positive effect on international beer export, is trade with neighbouring countries. The variable is strongly statistically significant, the coefficient varies between 0.87 (in terms of export quantity) and 0.97 (in terms of export value). Countries sharing common borders tend to trade $139-164 \%$ more other countries. The fact that trade between contiguous countries is enhanced is also reported in the study of Olper et al. (2012), where the effect for European beer export was $228 \%$ and for wine export $153 \%$.

Colonial links between trading partners positively influence international beer export (coefficient 1.38 - 1.44). Importers currently having a colonial link to the exporter trade approximately $297-322 \%$ more than countries without a current colonial link. The influence of trading partners being a part of one country was found not statistically significant.

We found (model $\mathrm{C}$ and $\mathrm{F}$ ) a significant and positive effect of signed FTAs and membership in customs unions on the volume of beer exports; the trade creating effect ranges between $40-63 \%$ compared to countries, which are not members of CU or without FTAs. However, these results failed to be significant according other estimated models, therefore, we consider the hypothesis H4 not confirmed. The free trade agreement effect in beer sector was analysed also by Dreyer et al. (2017) in terms of the membership of German beer importers in the EU, and while the least square estimation showed a positive influence of FTAs on export, this result was not robust according to PPML. Next, we estimated the influence of common currency used by trading countrypairs. As the variable is not statistically significant, it shows that beer exports are not sensitive to a use of common currency. Dreyer et al. (2017) found a beer trade-increasing effect of Euro, but the effect of the variable does not appear in our sample, which includes countries sharing also other currencies.

Our further findings show that transport costs (proxied by geographical distance, landlockedness and island separation) play an important role in beer export dynamics. Geographical distance is a conventional gravity model variable. Its coefficient proved statistically significant at the $1 \%$ level and it ranges between -0.82 and -0.85 . It proves the hypothesis $\mathrm{H} 3$ that trade falls with distance, specifically, a $10 \%$ increase in distance between trading countries lowers the international beer export by $8.2-8.5 \%$. This result is consistent with the result for European beer exports estimated by Olper et al. (2012), coeff. -0.91 . The influence of the landlockedness is strongly significant and the coefficient is negative as expected. We found that if at least one of the trading partners is land-locked, their trade is $74-78 \%$ lower than otherwise. The effect of importing countries being islands could not have been estimated in the corresponding fixed effect models.

Because of multicollinearity issue, the effect of religion and importer country belonging to the European continent could not have been estimated in the well-specified fixed effect models, and we cannot comment on their trade changing effect.

To conclude, international trade with beer is enhanced by cultural and geographical proximity of countries and trade cost play a significant trade-reducing role. Our findings are generally in line with the development on the international beer market outlined in the literature review of this paper; the estimation brings robust results across the specified models. This paper adds to the existing literature in following ways: we use a methodological approach appropriate to deal with zero trade flows and heteroscedasticity of trade data (PPML); we introduce fixed effects for controlling for the multilateral resistance terms; we adopt a great number of observations and create a vast database on beer trade-influencing factors, which can be used as a base for further research.

\section{Conclusion}

The objective of this paper was to identify determinants of international beer export using the gravity model approach with fixed effects. The estimated models explain more than $87 \%$ of the international beer export variability. The unexplained variability could be related to factors such as trade openness of countries, changes of specific tariffs or exchange rates, not covered by our model.

According to estimation results, international beer exports in the period of $2000-2017$ were 
positively influenced by the gross domestic product of importing countries. We estimated the income elasticity of beer to be positive, which indicates that beer is considered a superior good. Countries sharing common borders, same language or colonial past tend to trade beer more than countries without such relationships. Trade between contiguous countries benefits from low transport costs. The knowledge of the trading partner's language is especially important in the case of bottled or canned beer, which contains information about the traded product on the label. Furthermore, common language reduces transaction costs. In addition, we found a positive effect of FTAs or/and customs unions, which members tend to trade more than non-members. Results reveal that for our sample of countries, beer exports are not sensitive to a use of common currency.

Beer export activities are negatively influenced by the distance between trading countries and their landlockedness - proxy variables for transport cost of beer in international space. According to the results, change in beer exported is not significantly linked to changes in its production, which means that there are other more important factors determining how much beer produced is being exported (e.g. changes in own consumption in exporter country, results of economies of scale). As importer's population size and trade are negatively correlated, beer exporters can benefit from exporting to less populated countries with smaller self-production or less differentiated supply of beer.

\section{Acknowledgments}

This work was supported by the Slovak Research and Development Agency under the contract APVV-16-0321 and the Scientific Grant Agency VEGA No. 1/0928/17. The authors further acknowledge financial support from the Czech Science Foundation (GACR), grant No. 19-18080S.

\author{
Corresponding authors \\ Ing. Eva Bieleková, PhD. \\ Department of Economic Policy, Faculty of Economics and Management \\ Slovak University of Agriculture in Nitra, Trieda A. Hlinku 2, 94976 Nitra, Slovak Republic \\ Phone: +42137641 5891,E-mail: eva.bielekova@uniag.sk \\ ORCID: https://orcid.org/0000-0002-1576-2943
}

\title{
References
}

[1] Albertin, G. (2008) "Trade Effects of Currency Unions: Do Economic Dissimilarities Matter?", IMF working paper No. 08/249. [Online]. Available: https://papers.ssrn.com/sol3/papers. cfm?abstract_id=1316717 [Accessed: 3 June 2019].

[2] Anderson, J. E. (1979) “A theoretical foundation for the gravity equation", The American Economic Review, Vol. 69, No. 1, pp. 106-116. E-ISSN 19447981.

[3] Ashley, M. J. and Rankin, J. G. (1988) "A public health approach to the prevention of alcohol-related health problems", Annual Review Of Public Health, Vol. 9, pp. 233-271. DOI 10.1146/annurev.pu.09.050188.001313.

[4] Baldwin, R., Skudelny, F. and Taglioni, D. (2005) "Trade effects of the euro. Evidence from sectoral data", Working paper No. 446. [Online]. Available: http://ssrn.com/abstract_id=668246 [Accessed: 3 June 2019].

[5] Balogh, J. M. (2015) "Investigating the effect of geographical distances and cultural proximity on the Hungarian wine trade", Society and Economy, Vol. 37, No. 4, pp. 513-529. E-ISSN 1588-970X, ISSN 1588-9726.

[6] Berger, H. and Nitsch, V. (2008) "Zooming out: The trade effect of the euro in historical perspective", Journal of International Money and Finance, Vol. 27, No. 8, pp. 1244-1260. ISSN 0261-5606. DOI 10.1016/j.jimonfin.2008.07.005.

[7] Bjelić, P. (2016) "Trade facilitation and non-tariff measures in beverages and auto-parts supply chains in CEFTA", Technical Report, UN Conference on Trade and Development, Eschborn, Germany, 81 p. DOI 10.13140/RG.2.2.31972.78720. 
[8] Bouët, A., Emlinger, C. and Lamani, V. (2017) "What determines exports of luxury products? The case of cognac", Journal of Wine Economics, Vol. 12, No. 1, pp. 37-58. E-1931-437X, ISSN 1931-4361. DOI 10.1017/jwe.2017.2.

[9] Buch, C. M., Kleinert, J. and Toubal, F. (2004) "The distance puzzle: on the interpretation of the distance coefficient in gravity equations", Economics Letters, Vol. 83, No. 3, pp. 293-298. ISSN 0165-1765. DOI 10.1016/j.econlet.2003.10.022.

[10] Burger, M. J., Linders, G-J. M. and van Oort, F. (2009) "On the specification of the gravity model of trade: zeros, excess zeros and zero-inflated estimation”, Spatial Economic Analysis, Vol. 4, No. 2 , pp. 167-190. E-ISSN 1742-1780, ISSN 1742-1772. DOI 10.1080/17421770902834327.

[11] Costa-i-Font, J. (2010) "Regional single currency effects on bilateral trade with the European union". LEQS paper No. 26/2010. [Online]. Available: https://papers.ssrn.com/sol3/papers.cfm?abstract $\mathrm{id}=1699805$ [Accessed: 23 May 2019].

[12] Dal Bianco, A., Boatto, V. L., Caracciolo, F. and Santeramo, F. G. (2015) "Tariffs and non-tariff frictions in the world wine trade", European Review of Agricultural Economics, Vol. 43, No. 1, pp. 31-57. ISSN 1464-3618, ISSN 0165-1587. DOI 10.1093/erae/jbv008.

[13] De Matteis, M. C., Tun-Hsiang, E. Y., Boyer, Ch. N. and DeLong, K. L. (2018) “Analyzing determinants of U.S. distillers dried grains with solubles exports”, Agribusiness, Vol. 35, No. 2, pp. 168-181. E-ISSN1520-6297. DOI 10.1002/agr.21575.

[14] Dreyer, H., Fedoseeva, S., Herrmann, R. (2017). "Gravity meets pricing to market: what a combinedmethod approach tells us on German beer exports and pricing", Journal of economics and statistics, Vol. 237, No. 4, pp. 295-328. ISSN 2366-049X.

[15] Ekanayake, E. M., Mukherjee, A. and Veeramacheneni, B. (2010) "Trade blocks and the gravity model: A study of economic integration among Asian developing countries", Journal of Economic Integration, Vol. 25, No. 4, pp. 627-643. E-ISSN 1976-5525.

[16] Fogarty, J. (2010) "The demand for beer, wine and spirits: A survey of the literature", Journal of Economic Surveys, Vol. 24, No. 3, pp. 428-478. E-ISSN:1467-6419. DOI 10.1111/j.1467-6419.2009.00591.x.

[17] Giorgio, R. (2004) "Empirical evidence on the north-south trade flows: An augmented gravity model", MPRA paper No. 1326. [Online]. Available: https://mpra.ub.uni-muenchen.de/1326/1/ MPRA_paper_1326.pdf [Accessed: 22 May 2019].

[18] Goméz-Corona, C., Escalona-Buendía, H. B., Garcia, M., Chollet, S. and Valentin, D. (2016) "Craft vs. industrial: Habits, attitudes and motivations towards beer consumption in Mexico", Appetite, Vol. 96, pp. 358-367. ISSN 0195-6663. DOI 10.1016/j.appet.2015.10.002.

[19] Madsen, E. S. and Wu, Y. (2016) "Marketing and globalization of the brewing industry", In Cabras, I., Higgins, D. and Preece, D. (eds) "Brewing, beer and pubs", London, Palgrave Macmillan, pp. 34-53. ISBN 978-1-137-46618-1. DOI 10.1057/9781137466181_3.

[20] Márquez-Ramos, L., Martínez-Zarzoso, I. and Suárez-Burguet, C. (2007) "The role of distance in gravity regressions: is there really a missing globalisation puzzle?", Journal of Economic Analysis and Policy, Vol. 7, No. 1. ISSN 1935-1682. DOI 10.2202/1935-1682.1557.

[21] McGowan, R. S. J. and Mahon, J. F. (2007) "U.S. beer flows \& the impact of NAFTA", Management \& Marketing, Vol. 5, No. 1, pp. 39-54. ISSN 2069-8887.

[22] Moulton, B. (1990) "An illustration of the pitfall in estimating the effects of aggregate variables on micro units", Review of Economics And Statistics, Vol. 72, No. 2, pp. 334-338. E-ISSN 1530-9142. DOI 10.2307/2109724.

[23] Olper, A., Curzi, D., Frisio, D. G. and Raimondi, V. (2012) "Home bias in consumption: A comparison between wine and beer", German Journal of Agricultural Economics, Vol. 61, No. 4, pp. 223-234. ISSN 2191-4028. 
[24] Pinilla, V. and Serrano, R. (2008) "The agricultural and food trade in the first globalization: Spanish table wine exports 1871 to 1935 - A case study", Journal of Wine Economics, Vol. 3, No. 2, p. 132-148. E-ISSN 1931-437X, ISSN 1931-4361. DOI 10.1017/S1931436100001176.

[25] Pokrivčák, J., van Berkum, S., Drgova, L., Mraz, M., Ciaian, pp. (2013). "The role of non-tariff measures in EU dairy trade with Russia”, Post-communist economies, Vol. 25, No. 2, pp. 175-189. DOI 10.1080/14631377.2013.787737.

[26] Pokrivčák, J., Lančarič, D., Savov, R. and Tóth, M. (2017) "Craft beer in Slovakia", In Garavaglia, C., Swinnen, J. "Economic perspectives on craft beer: A revolution in the global beer industry", Cham, Switzerland, Palgrave Macmillan. ISBN 978-3-319-58235-1. DOI 10.1007/978-3-319-58235-1_12.

[27] Pokrivčák, J., Supeková, S. C., Lančarič, D., Savov, R., Tóth, M. and Vašina, R. (2019) “Development of beer industry and craft beer expansion", Journal of Food and Nutrition Research, Vol. 58, No. 1, pp. 63-74. ISSN 1338-4260.

[28] Ramsey, J. B. (1969) "Tests for specification errors in classical linear least squares regression analysis”, Journal of royal statistical society, Vol. 31, No. 2, pp. 350-371. E-ISSN 1467-985X. DOI 10.1080/14631377.2013.787737.

[29] Rose, A. K. and Stanley, T. D. (2005) "A meta-analysis of the effect of common currencies on international trade", Journal of Economic Surveys, Vol. 19, No. 3, pp. 347-365. E-ISSN:1467-6419. DOI 10.1111/j.0950-0804.2005.00251.x.

[30] Silva, S. and Tenreyro S. (2006) "The log of gravity", The Review of Economics And Statistics, Vol. 88, No. 4, pp. 641-658. E-1530-9142. ISSN 0034-6535. DOI 10.1162/rest.88.4.641.

[31] Shepherd, B. (2013) "The gravity model of international trade: A user guide", Bangkok, United Nations publications, p. 76. ISBN-13 978-974-680-346-5.

[32] Swinnen, J. (2017) "Beer consumption and trade in an era of economic growth and globalization", Choices, Vol. 32, No. 3, pp. 1-6. E-ISSN 2162-2884, ISSN 0886-5558. DOI 10.22004/ag.econ.263133.

[33] Tinbergen, J. (1962) "Shaping the world economy; Suggestions for an international economic policy", New York, USA, Twentieth Century Fund, p. 330. ISBN-10: 1258384302, ISBN-13: 978-1258384302. DOI 10.2307/1236502.

[34] Thom, R. and Walsh, B. (2002) "Effect of a common currency on trade: lessons from the Irish experience", European Economic Review, Vol. 46, No. 6, pp. 1111-1123. ISSN 0014-2921. DOI 10.1016/S0014-2921(01)00203-3.

[35] Tremblay, V. J. and Tremblay, C. H. (2004) "The US brewing industry: data and economic analysis", Cambridge, USA, MIT Press, p. 400. ISBN-13 978-0262201513.

[36] Zeigler, D. W. (2008) "The alcohol industry and trade agreements: a preliminary assessment", Addiction, Vol. 104, No. s1, pp. 13-26. E-ISSN 1360-0443. DOI 10.1111/j.1360-0443.2008.02431.x.

[37] Wine Institute. (2019) “International trade policy". Wine Institute. [Online]. Available: https://www.wineinstitute.org/international_trade_policy [Accessed: 23 May 2019]. 